Journal of Clinical Investigation

Vol. 42, No. 12,1963

\title{
GAMMA GLOBULIN TURNOVER AND INTESTINAL DEGRADATION OF GAMMA GLOBULIN IN THE DOG*
}

\author{
By STIG BRYDE ANDERSEN, JØRGEN GLENERT, AND KNUT WALLEVIK \\ (From Bispebjerg Hospital, Department of Clinical Biochemistry, Copenhagen, and from the \\ Institute of Experimental Research in Surgery, University of Copenhagen,
}

Denmark)

(Submitted for publication February 14, 1963 ; accepted August 16, 1963)

Increased catabolism of plasma proteins by leakage into the gastrointestinal tract and subsequent digestion by the intestinal enzymes are frequently the causes of hypoproteinemia (1-5). The presence of plasma proteins has been demonstrated both in saliva and in the gastric and intestinal juice of normal individuals; therefore, gastrointestinal leakage of plasma proteins may account for a substantial part of their normal degradation (6-12). The passage of plasma albumin into the intestine has been studied quantitatively by $\mathrm{I}^{131}$-labeled albumin. This technique is complicated by the secretion of inorganic iodide in saliva and gastric juice $(13,14)$ and by secretion and reabsorption of iodide in the small intestine $(12,15)$. Consequently, only transfer of proteinbound radioactivity is a measure of transfer of $I^{131}$-labeled protein. In man one-third of the total amount of albumin catabolized was found to be broken down in the gastrointestinal tract (8), and in logs from one-half to two-thirds of albumin catabolism was found to be due to gastrointestinal leakage (12). In sheep a substantial amount of albumin was recovered from the intestinal contents without inhibiting the proteolytic enzymes (9). Jeejeebhoy and Coghill (10) estimated that $50 \%$ of albumin catabolism takes place in the gastrointestinal tract of man; they measured fecal radioactivity after oral administration of an ionexchange resin. Thus iodide passing into the intestinal lumen is bound by the resin and excreted in the stool. Their figure, however, may not reflect intestinal catabolism, since the fecal radioactivity may have been derived from nonproteinbound iodide secreted in the gastrointestinal juice (15).

All classes of plasma proteins seem to leak into the gastrointestinal lumen (6), but only albumin

* This work was supported by a grant from the P. Carl Petersen Foundation. has been studied quantitatively. In the present investigation, the role of the small intestine for the catabolism of gamma globulin has been studied in the dog. The total turnover was determined by isolated and $\mathrm{I}^{131}$-labeled canine gamma globulin. Four to 7 weeks later another dose of $\mathrm{I}^{131}$-labeled gamma globulin was injected into the same dogs, and the transfer of protein-bound radioactivity from plasma to the lumen of intestinal segments was measured.

\section{METHODS}

Material. The study was carried out in ten mongrel dogs weighing 4.3 to $16.5 \mathrm{~kg}$. All were apparently healthy; hemoglobin, hematocrit, plasma proteins, and serum creatinine were normal. Autopsy at the end of each experiment revealed normal organs.

Gamma globulin was isolated from the serum of normal dogs by column chromatography on diethylaminoethyl (DEAE) cellulose ${ }^{1}$ (16). Serum was dialyzed overnight against the elution buffer (phosphate $0.01 \mathrm{M}, \mathrm{pH}$ 8.2). The gamma globulin peak was located by measurement of the ultraviolet absorption of eluate at $210 \mathrm{~m} \mu$ diluted $1: 120$ in saline (17). The pooled fractions of the peak (about $50 \mathrm{ml}$ ) were sterilized and filtered through a glass filter (Jena $17 \mathrm{G} 5$; pore diameter, 1 to $1.5 \mu$ ), and the solution was concentrated at 2 to $3 \mathrm{ml}$ by vacuum dialysis. The yield was about $50 \mathrm{mg}$ in each preparation.

Iodination. The protein was labeled with carrier-free $\mathrm{I}^{131}$ without reducing agent. ${ }^{2}$ Iodine monochloride was used as inactive carrier solution according to the method of McFarlane (18). Nonprotein-bound $I^{131}$ was removed by a resin column (Amberlite IRA-400). An average of $33 \%$ of the initial radioactivity passed through the column, and an average of $0.9 \%$ of this was present in the supernatant fluid after precipitation with $10 \%$ trichloroacetic acid. The mean ratio of iodine bound to protein (mol wt, 160,000) was on an average, 1.9 atoms per molecule. An average of $6.2 \mu \mathrm{c}$ was bound per $\mathrm{mg}$ of protein. The labeled gamma globulin was mixed with normal dog serum and examined by paper electrophoresis; subsequent strip counting showed that, on an aver-

1 Eastman-Kodak Co., Rochester, N. Y.

2 Radiochemical Centre, Amersham, England. 
age, $87 \%$ of the radioactivity was confined to the gamma globulin region and $13 \%$ to the $\beta_{2}$-globulin peak. Radioautography of paper electrophoresis gave a broad uniform blackening of the film in the gamma region and a faint, narrow band in the $\beta_{2}$-region. Inactive human serum albumin $^{3}$ was added to a concentration of about $20 \mathrm{mg}$ per $\mathrm{ml}$ in the final solution, partly to prevent adsorption to glassware (19) and partly to prevent damage of the protein by selfirradiation (20). Six different $\mathrm{I}^{131}$ labeled gamma globulin preparations were used in the studies.

Paper electrophoresis. Calcium ions were added to the Veronal buffer, and protein fractions were determined spectrophotometrically by elution of paper electrophoretic strips stained with bromphenol blue (21). The gamma globulin concentration is underestimated by this technique because the stainability of gamma globulin is lower than that of albumin by a factor 0.59 (22). Therefore, before calculating the protein fractions, the extinction of the elution of the gamma globulin band was corrected by a factor $1.69(=1 / 0.59)$.

Total serum protein concentrations for calculation of paper electrophoresis were determined by Kjeldahl analysis with a conversion factor of 6.25 after correction for nonprotein nitrogen.

Turnover of gamma globulin. The dogs received potassium iodide (125 $\mathrm{mg}$ per day) for 2 days before and subsequently through the period of blood sampling. A volume of 1 to $5 \mathrm{ml}$ of labeled gamma globulin (2 to $10 \mathrm{mg}, 10$ to $20 \mu \mathrm{c}$ ) was injected intravenously; the dose injected was determined by weighing the syringe before and after injection. Blood samples were collected into tubes containing dried heparin. The first plasma sample was taken after 15 minutes and daily for at least 2 weeks thereafter. The radioactivity of plasma was measured by scintillation counting in a well-type sodium iodide crystal (Tracerlab Versamatic). Plasma specific activities were calculated from daily plasma protein estimations by the biuret method.

The turnover of gamma globulin was calculated by mathematical analysis of the plasma disappearance curve (23). The method is based on metabolic steady state and on the assumption that degradation and synthesis of the protein take place intravascularly or in a compartment in rapid exchange with plasma. The following calculations were made: plasma volume $(P V)=$ injected dose $\times 0.98 /$ plasma activity per milliliter after 15 minutes, with an elimination to extravascular compartments of $2 \%$ in 15 minutes; plasma pool of gamma globulin = plasma volume $\times$ gamma globulin concentration; fractional turnover rate $(F)=$ fraction of plasma pool catabolized per day ; rate of synthesis = absolute amount of gamma globulin catabolized (or synthesized) per day; metabolic clearance $\left(\mathrm{Cl}_{\text {met }} /\right.$ day $)=$ volume of plasma containing the amount of gamma globulin catabolized daily $\left(\mathrm{Cl}_{\text {met }} /\right.$ day $=\mathrm{F} \times \mathrm{PV}$ ); distribution ratio = ratio between extravascular pools and plasma pool; exchange rate $=$ fraction

${ }^{3}$ Statens Seruminstitut, Copenhagen, Denmark. of plasma pool transferred to extravascular compartments daily.

Experimental procedure. The gamma globulin turnover was, as described, determined in each dog by intravenous injection of labeled gamma globulin. Four to 7 weeks later, the passage of gamma globulin from plasma to the intestinal lumen was determined in the same dogs by measuring the amount of protein-bound radioactivity transferred to isolated intestinal segments after a new intravenous injection of $\mathrm{I}^{131}$-labeled gamma globulin. About $50 \mu \mathrm{c}$ per $\mathrm{kg}$ was injected from 2 to 4 hours before laparotomy, which was done during Nembutal anesthesia supplemented with endotracheal $\mathrm{N}_{2} \mathrm{O}-\mathrm{O}_{2}$. Three segments, one orally, one anally, and one about the middle of the small intestine, were isolated between tape ligatures. The segments were 30 to $50 \mathrm{~cm}$ long (Table III). The ligature at the oral end of each segment was fastened around a thin Nelaton catheter introduced through an enterostomy at the oral end of the segment. This simple technique has given similar results to other, perhaps more physiological but technically much more laborious, methods (12). During the surgical procedure, the intestine was handled gently, and the surface was kept moist and warm.

The segments were rinsed 15 to 20 times until the saline used was clear, and at the end of this procedure, a sample was checked for radioactivity. The segments were then filled with $22.5 \mathrm{ml}$ saline containing soybean trypsin inhibitor (TI), $40.5 \mathrm{mg}$ per $\mathrm{ml}$; thus the segments were at most slightly distended. Ten minutes later the solution was aspirated; in a 4-ml sample, protein-bound activity was determined by immediately precipitating with an equal volume of $10 \%$ trichloroacetic acid; $0.5 \mathrm{ml}$ $20 \%$ human albumin was added as carrier. This procedure was performed from 2 to 4 times on each segment. On an average, $90 \%$ of the solution instilled could be aspirated, i.e., about $20 \mathrm{ml}$. All samples aspirated were tested for blood by benzidine; a few were positive and therefore discarded. The completeness of the inhibition of proteolysis by the TI was studied in one dog into which no radioactive protein had been injected. Each of two isolated segments of the small intestine, one proximally and one distally, was filled with a solution of $\mathrm{I}^{131}$-labeled gamma globulin. After 10 minutes the solution was aspirated, and the percentage of protein-bound radioactivity was determined. This procedure was repeated 3 times. Three similar experiments were performed after TI $(0.5 \mathrm{mg}$ per $\mathrm{ml})$ had been added to the $\mathrm{I}^{131}$-labeled gamma globulin solutions. The results showed that an average of $1.2 \%$ nonprotein-bound radioactivity was found in the aspirates whether TI was added or not. No difference was found between the proximal and distal part of the intestine.

An attempt to change the gamma globulin transfer was made in all dogs. In two experiments the influx of fluid to the lumen of the segments was increased by the use of TI solutions made hypertonic by addition of a

4 Soybean trypsin inhibitor was kindly supplied by A/S Novo, Copenhagen, Denmark. 
TABLE I

Turnover data of gamma globulin in dogs*

\begin{tabular}{|c|c|c|c|c|c|c|c|c|c|c|c|c|c|c|c|}
\hline & \multirow[t]{2}{*}{ Sex } & \multirow{2}{*}{$\frac{\text { Weight }}{k g}$} & \multicolumn{2}{|c|}{$\begin{array}{c}\text { Plasma } \\
\text { volume }\end{array}$} & \multirow{2}{*}{$\begin{array}{c}\begin{array}{c}\text { Serum } \\
\text { gamma } \\
\text { globulin }\end{array} \\
\mathrm{g} / 100 \mathrm{ml}\end{array}$} & \multicolumn{2}{|c|}{$\begin{array}{l}\text { Plasma pool of } \\
\text { gamma globulin }\end{array}$} & \multirow{2}{*}{$\begin{array}{c}\begin{array}{c}\text { Frac- } \\
\text { tional } \\
\text { turn- } \\
\text { over } \\
\text { rate }\end{array} \\
\%\end{array}$} & \multicolumn{2}{|c|}{ Rate of synthesis } & \multirow{2}{*}{$\begin{array}{c}\begin{array}{c}\text { Ex- } \\
\text { change } \\
\text { rate }\end{array} \\
\%\end{array}$} & \multirow[t]{2}{*}{$\begin{array}{c}\text { Distri- } \\
\text { bution } \\
\text { ratio, } \\
\mathbf{E} / \mathbf{P}\end{array}$} & \multirow{2}{*}{$\begin{array}{c}\begin{array}{c}\text { Plasma } \\
\text { dis- } \\
\text { appear- } \\
\text { ance } \\
\text { half- } \\
\text { life }\end{array} \\
\text { days }\end{array}$} & \multirow{2}{*}{$\begin{array}{c}\begin{array}{c}\text { Length } \\
\text { of } \\
\text { study }\end{array} \\
\text { days }\end{array}$} & \multirow{2}{*}{$\frac{\begin{array}{c}\text { Metabolic } \\
\text { clearance }\end{array}}{m l / d a y}$} \\
\hline & & & $m l$ & $\underset{k g}{m l /}$ & & $g$ & $\mathrm{~g} / \mathrm{kg}$ & & $\stackrel{g /}{d a y}$ & $\underset{\text { day }}{\mathrm{mg} / \mathrm{kg} /}$ & & & & & \\
\hline Pernille & $\mathbf{F}$ & 13.9 & 687 & 48.8 & 0.98 & 6.73 & 0.48 & 23.3 & 1.57 & 113 & 35 & 0.77 & 6.7 & 21 & 160 \\
\hline Basse & $\mathbf{M}$ & 13.9 & 604 & 43.5 & 0.98 & 5.92 & 0.43 & 12.8 & 0.76 & 55 & 46 & 0.72 & 9.9 & 20 & 77 \\
\hline Rikke & $\mathbf{F}$ & 13.4 & 701 & 52.3 & 0.79 & 5.54 & 0.41 & 13.5 & 0.75 & 56 & 51 & 0.61 & 8.6 & 14 & 91 \\
\hline Valdemar & $\mathbf{M}$ & 13.3 & 613 & 46.2 & 1.05 & 6.43 & 0.48 & 22.6 & 1.45 & 109 & 29 & 0.49 & 5.6 & 19 & 139 \\
\hline Hugo & $\mathbf{M}$ & 12.5 & 560 & 44.8 & 0.97 & 5.43 & 0.43 & 17.3 & 0.94 & 75 & 26 & 0.48 & 6.4 & 20 & 97 \\
\hline Walther & $\mathbf{M}$ & 10.7 & 482 & 45.1 & 0.85 & 4.10 & 0.38 & 21.2 & 0.87 & 81 & 58 & 1.23 & 9.2 & 21 & 102 \\
\hline Sofus & $\mathbf{M}$ & 9.2 & 412 & 44.7 & 0.90 & 3.71 & 0.40 & 24.4 & 0.91 & 98 & 46 & 0.72 & 6.2 & 18 & 101 \\
\hline Rigmor & $F$ & 6.4 & 299 & 46.7 & 1.10 & 3.29 & 0.51 & 18.4 & 0.61 & 95 & 46 & 0.58 & 6.5 & 14 & 55 \\
\hline Hagbart & $\mathbf{M}$ & 6.3 & 310 & 49.2 & 1.18 & 3.66 & 0.58 & 23.2 & 0.85 & 134 & 37 & 0.75 & 5.9 & 14 & 72 \\
\hline Signe & $\mathrm{F}$ & 4.3 & 262 & 60.9 & 1.08 & 2.83 & 0.66 & 28.5 & 0.81 & 188 & 56 & 0.81 & 4.9 & 14 & 75 \\
\hline Mean & & 10.4 & 493 & 48.2 & 0.99 & 4.76 & 0.48 & 20.5 & 0.95 & 64 & 43 & 0.72 & 7.0 & 17.5 & 97 \\
\hline SE & & 1.1 & 52 & 1.6 & 0.038 & 0.45 & 0.028 & 1.5 & 0.098 & 8.3 & 3.4 & 0.07 & 0.5 & 1.0 & 10.0 \\
\hline
\end{tabular}

* Exchange rate and fractional turnover rate are expressed as percentages of plasma pool per day. Distribution ratio indicates the fraction between the sum of extravascular pools $(E)$ and plasma pool $(P)$.

$50 \%$ solution of $\mathrm{MgSO}_{4}$; osmolarity was increased 2 to 4 times. 120 to $140 \%$ of the volume instilled could be aspirated ( 26 to $32 \mathrm{ml}$ ). In the remaining five dogs the portal vein was clamped for 10 to 60 minutes. The degree of venous stasis was estimated by edema of the intestine and by the number of petechiae in the mesentery.

All animals were killed at the end of the experiments; autopsy was done, and the segments and small intestine were measured tensed without $150 \mathrm{~g}$ (Table III).

Plasma radioactivity was determined from blood samples drawn before and after the experiments. The radioactivity during the experimental period was determined by interpolation.

Calculations. Plasma radioactivity $=Q_{p}$, counts per milliliter; total radioactivity in aspirated volume $=Q_{a}$, counts per milliliter; protein-bound radioactivity in aspirate (fraction of $Q_{2}$ ) $=P B$; length of segment investigated $=\mathrm{S}$ per cent of total length of small intestine.

Transfer of gamma globulin from plasma to intestinal lumen may now be expressed as intestinal clearance per minute per $100 \%$ of the small intestine $\left(\mathrm{Cl}_{1 \mathrm{nt}} /\right.$ minute $)$. If we assume that the over-all intestinal clearance is similar to the clearance of the segment investigated, $\mathrm{Cl}_{\text {int }} /$ minute $=\left(Q_{\mathrm{a}} \times \mathrm{PB} \times 100 \times 1,000\right) /\left(\mathrm{Q}_{\mathrm{p}} \times 10 \times \mathrm{S}\right)$ $\mu \mathrm{l} /$ minute.

Metabolic clearance per minute, $\mathrm{Cl}_{\mathrm{met}} /$ minute, is calculated from fractional turnover rate and plasma volume, $\mathrm{Cl}_{\text {met }} /$ minute $=(\mathrm{F} \times \mathrm{PV} \times 1,000) /(1,440 \times 100 \mu 1 /$ minute, since fractional turnover rate is expressed in percentage per day (1,440 minutes).

Passage of gamma globulin to the small intestine in percentage of total gamma globulin catabolism may now be estimated for each segment by the following formula (if we assume that the segment occupied $100 \%$ of the small intestine $):\left(\mathrm{Cl}_{\text {int }} /\right.$ minute $) /\left(\mathrm{Cl}_{\text {met }} /\right.$ minute $) \times 100 \%$.

$\mathrm{By}$ the average figure for the three segments, the trans- fer for the whole of the small intestine is estimated, if we assume that each segment represents one-third.

\section{RESULTS}

Turnover of gamma globulin. Data of the turnover studies are presented in Table I. Plasma volume varied from 43.5 to $60.9 \mathrm{ml}$ per $\mathrm{kg}$, serum gamma globulin from 0.79 to $1.18 \mathrm{~g}$ per 100 $\mathrm{ml}$, and plasma pool of gamma globulin from 0.38 to $0.66 \mathrm{~g}$ per $\mathrm{kg}$.

Plasma radioactivity plotted on a semilogarithmic scale showed initially the usual rather rapid decrease associated with mixing of labeled molecules with extravascular protein. After 3 to 10 days this phase was followed by a linear rate of decrease; the curves were followed for at least 8 days after they had become linear. Half-lives calculated from this portion of the plasma curve varied from 4.9 to 9.9 days. In five dogs the curve could be analyzed into three exponential functions; in the remaining five dogs it could only be resolved into two exponentials. Fractional turnover rate varied from 12.8 to $28.5 \%$ of plasma pool per day (average 20.5\%). A negative correlation between fractional turnover rate and body weight was found ( $r=-0.65 ; 0.05>p>0.02)$. The rate of synthesis was from 55 to $188 \mathrm{mg}$ per $\mathrm{kg}$ per day or from 0.61 to $1.57 \mathrm{~g}$ per day. No significant correlation between rate of synthesis 
TABLE II

Data of experiments on intestinal degradation of gamma globulin*

\begin{tabular}{|c|c|c|c|c|c|c|c|c|c|c|c|}
\hline & \multirow[b]{2}{*}{$\mathrm{Cl}_{\text {met }} / \mathrm{min}$} & \multicolumn{3}{|c|}{$\begin{array}{l}\text { Protein-bound activity } \\
\text { in aspirate } \dagger\end{array}$} & \multicolumn{3}{|c|}{$\mathrm{Cl}_{\text {int }} / \min \dagger$} & \multicolumn{4}{|c|}{$\begin{array}{c}\text { Intestinal degradation in percentage } \\
\text { of total turnover } \\
\mathrm{Cl}_{\text {int }} / \mathrm{Cl}_{\text {met }} \times 100 \%\end{array}$} \\
\hline & & Proximal & Middle & Distal & Proximal & Middle & Distal & Proximal & Middle & Distal & Average \\
\hline & $\mu l$ & $\%$ & $\%$ & $\%$ & $\mu l$ & $\mu l$ & $\mu l$ & $\%$ & $\%$ & $\%$ & $\%$ \\
\hline Pernille & 111.2 & 36 & 50 & 37 & 29 & 32 & 9 & 26 & 29 & 8 & 21 \\
\hline Hugo & 67.2 & 54 & 62 & 58 & 17 & 15 & 16 & 25 & 22 & 24 & 24 \\
\hline Walther & 70.8 & 43 & 77 & 78 & 27 & 44 & 40 & 38 & 62 & 57 & 52 \\
\hline Sof us & 69.8 & 68 & 52 & 44 & 33 & 19 & 29 & 47 & 27 & 42 & 39 \\
\hline Rigmor & 38.2 & 67 & 29 & & 19 & 6 & & 50 & 16 & & 33 \\
\hline Hagbart & 49.9 & 10 & 19 & 21 & 6 & 18 & 8 & 12 & 26 & 16 & 21 \\
\hline Signe & 51.8 & 46 & 65 & 69 & 38 & 34 & 43 & 73 & 66 & 83 & 74 \\
\hline Mean & 65.5 & 46 & 51 & 51 & 24 & 24 & 24 & 39 & 37 & 38 & 38 \\
\hline $\mathrm{SE}$ & 8.9 & 7.5 & 7.7 & 8.7 & 4.0 & 5.0 & 6.3 & 7.6 & 7.4 & 11.5 & 3.8 \\
\hline
\end{tabular}

${ }^{*}$ For each part of the small intestine, the intestinal clearance per minute $\left(\mathrm{Cl}_{\text {int }} / \mathrm{min}\right)$ was calculated as if the whole of the small intestine had the same intestinal clearance as the segment studied. $\quad \mathrm{Cl}_{\mathrm{met}} / \mathrm{min}=$ metabolic clearance per minute.

$\dagger$ Average of 2 to 4 determinations.

and body weight was found $(r=0.48 ; \mathrm{p}>0.1)$. The distribution ratio of extravascular to intravascular gamma globulin was 0.48 to 1.23 (mean, 0.72 ), which means that on an average $58 \%$ of the total pool of gamma globulin was found intravascularly. The exchange rate of gamma globulin from plasma to extravascular pools varied from 26 to $58 \%$ of the plasma pool per day (mean, $43 \%)$.

The metabolic clearance $(24,25)$ indicates the volume of plasma containing the amount of gamma globulin catabolized per unit of time. It is a convenient parameter when the metabolism is related to the transfer from plasma to intestine as done in the present study. The metabolic clearance, $\mathrm{Cl}_{\text {met }}$, usually is calculated from urinary excretion of radioactivity, $Q_{\mathfrak{u}}$, and the plasma activity per milliliter, $Q_{\mathrm{p}}: \mathrm{Cl}_{\text {met }}=Q_{\mathrm{u}} / \mathrm{Q}_{\mathrm{p}} \mathrm{ml} /$ day.

In the present study, the metabolic clearance was calculated by the fractional turnover rate because the urinary excretion of radioactivity was not measured. Since fractional turnover rate may be calculated from urinary excretion of radioactivity and the amount of activity in the plasma, we have $F=Q_{u} /\left(Q_{p} \times P V\right)=\mathrm{Cl}_{\text {met }} / P V$ or $\mathrm{Cl}_{\text {met }}=$ $\mathrm{F} \times \mathrm{PV}$. In the present study, fractional turnover rate was calculated by the plasma curve, but this method appears to give values for fractional turnover rate that are identical with the methods based on urinary excretion of the label $(23,26,27)$. The metabolic clearance was from 55 to $160 \mathrm{ml}$ per day, and a slight positive correlation with

TABLE III

Length of the small intestine and of each segment studied for intestinal degradation of gamma globulin

\begin{tabular}{|c|c|c|c|c|c|c|c|c|}
\hline & \multirow{2}{*}{$\begin{array}{c}\text { Length of small } \\
\text { intestine }\end{array}$} & \multicolumn{3}{|c|}{ Length of segments } & \multicolumn{3}{|c|}{$\begin{array}{l}\text { Length of segments in } \\
\text { percentage of total }\end{array}$} & \multirow{2}{*}{$\begin{array}{l}\text { Sum of all } \\
\text { three segments } \\
\text { in percentage } \\
\text { of total length }\end{array}$} \\
\hline & & Proximal & Middle & Distal & Proximal & Middle & $\overrightarrow{\text { Distal }}$ & \\
\hline & $\mathrm{cm}$ & $\mathrm{cm}$ & $\mathrm{cm}$ & $\mathrm{cm}$ & $\%$ & $\%$ & $\%$ & $\%$ \\
\hline Pernille & 390 & 40 & 33 & 40 & 10.3 & 8.5 & 10.3 & 29.1 \\
\hline Hugo & 358 & 31 & 34 & 28 & 8.7 & 9.5 & 7.8 & 26.0 \\
\hline Walther & 318 & 45 & 47 & 47 & 14.2 & 14.8 & 14.8 & 43.8 \\
\hline Sofus & 344 & 50.5 & 39 & 30 & 14.7 & 11.3 & 8.7 & 34.7 \\
\hline Rigmor & 278 & 40 & 39 & 33 & 14.4 & 14.0 & 11.9 & 40.3 \\
\hline Hagbart & 274 & 42 & 28 & 32 & 15.3 & 10.2 & 11.7 & 37.2 \\
\hline Signe & 222 & 40 & 41 & 30 & 18.0 & 18.5 & 13.5 & 50.0 \\
\hline Mean & 312 & 41 & 37 & 34 & 13.7 & 12.4 & 11.2 & 37.3 \\
\hline $\mathrm{SE}$ & 22 & 2.2 & 2.3 & 2.6 & 1.9 & 1.8 & 0.9 & 3.1 \\
\hline
\end{tabular}




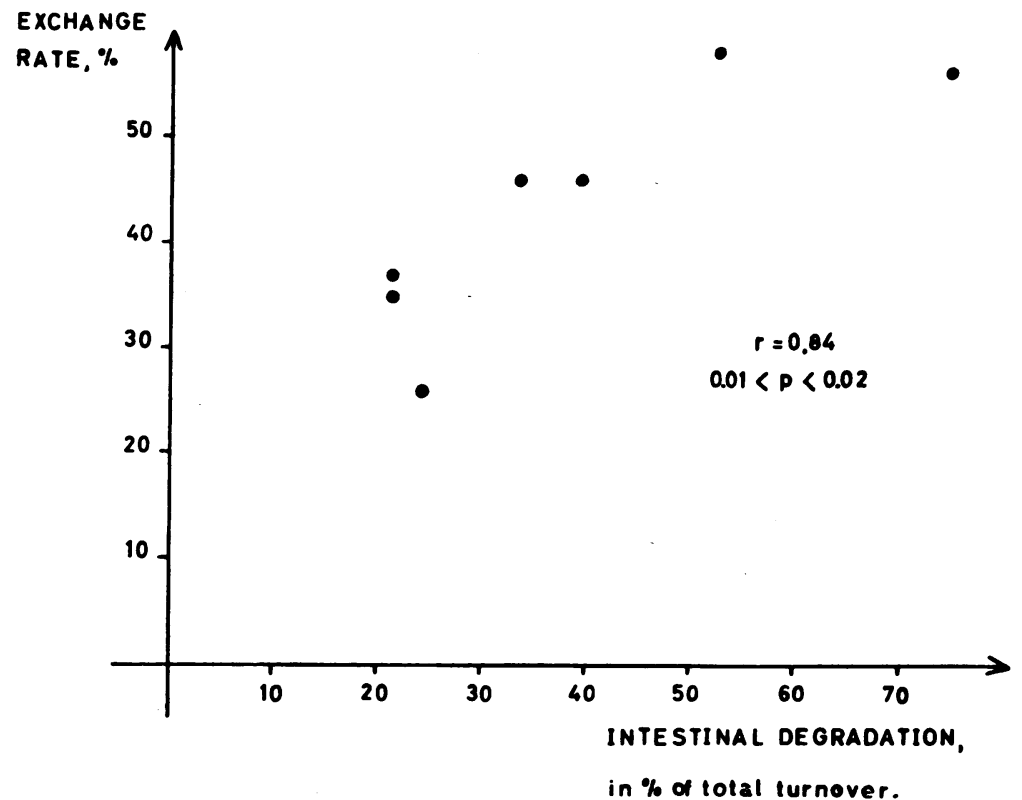

Fig. 1. The correlation between exchange rate of gamma globulin (CAPILlaRy PERMEability) AND INTESTINAL degradation OF GAMMA GLOBULIN IN PERCENTAGE OF TOTAL TURNOVER (INTESTINAL CLEARANCE/METABOLIC CLEARANCE).

body weight was found $(r=0.66 ; 0.02<\mathrm{p}<$ $0.05)$.

Intestinal degradation of gamma globulin. The results of these experiments are presented in Table II. Since the transfer of gamma globulin to the intestine is expressed as volume of plasma cleared per minute for a given length of gut, the metabolic clearance per minute is given in the first column; it varied from 38 to $111 \mu \mathrm{l}$ per minute. In the aspirates about $50 \%$ of the activity was protein bound, but a considerable variation was found. The intestinal clearance of each segment has been converted to account for $100 \%$ of the entire length of the small intestine, since the relative length of the segments varied considerably (Table III). On an average, the intestinal clearance was $24 \mu$ l per minute in the proximal, middle, and distal segments, but a wide variation was found. The intestinal clearance of each segment in proportion to the metabolic clearance of individual dogs is also given in Table II. Each segment is assumed to occupy the whole intestine, and therefore the average figure for the three segments indicates that fraction of the total turnover which is broken down intestinally if each segment represents one-third of the intestine. From
21 to $74 \%$ (mean, 38\%) was catabolized in the small intestine, and each part appeared to be equally responsible, since the average figures for the three segments were almost identical. A positive correlation was found between exchange rate and the fraction of total turnover broken down intestinally $(\mathrm{r}=0.84 ; 0.01<\mathrm{p}<0.02)$ (Figure 1). This might be due to a correlation between turnover rate and exchange rate, but no such correlation existed $(r=0.50 ; p>0.2)$.

After the experiments reported above, an in-

$$
\text { TABLE IV }
$$

Experimental increment of intestinal transfer of gamma globulin by instillation of hypertonic $\mathrm{MgSO}_{4}$ in the intestinal lumen or by clamping of the portal vein

\begin{tabular}{lccc}
\hline & $\mathrm{Cl}_{\text {int } / \mathrm{min}^{*}}$ & $\begin{array}{c}\mathrm{Cl}_{\text {int }} / \mathrm{min} \\
\text { after installation } \\
\text { of hypertonic } \\
\text { MgSO }\end{array}$ & $\begin{array}{c}\mathrm{Cl}_{\text {int }} / \mathrm{min} \\
\text { after clamping } \\
\text { of the portal } \\
\text { vein }\end{array}$ \\
\hline Hugo & $\mu l / \mathrm{min}$ & $\mu l / \mathrm{min}$ & $\mu l / \mathrm{min}$ \\
Sofus & 16 & 47 & \\
Walther & 27 & 63 & 62 \\
Pernille & 37 & & 371 \\
Hagbart & 23 & & 152 \\
Signe & 11 & & 111 \\
Rigmor & 38 & & 56 \\
\hline
\end{tabular}

* Intestinal clearance per minute. 
crement of the passage of gamma globulin to the lumen of the intestine was attempted in all dogs (Table IV). The influx of fluid was increased by the use of hypertonic TI solutions in two dogs. The transfer of protein-bound activity to the intestine was thereby increased about twice compared with the "normal" experiments. In the remaining dogs, the portal vein was clamped, and the transfer was thus increased up to 15 times. The venous stasis caused edema of the intestine and produced petechiae of the mesentery. The more pronounced these changes appeared to be, the higher was the rise in intestinal clearance.

\section{DISCUSSION}

Turnover of gamma globulin. Turnover data of plasma proteins have been reported by a number of different expressions from various laboratories. A full description of the turnover of a plasma protein should contain information about the pool size and the amount of protein turned over per day. The proportion between these two parameters indicates the turnover rate of the protein. If any two of these three parameters are known, the third one may be calculated. The turnover has often been expressed by the half-life of the plasma disappearance curve, since we assume that it reflects the turnover rate of the total pool. But this expression is insufficient, 1) because no information is given about the pool size and the amount of protein turned over per day and 2) because the plasma half-life will not reflect the turnover of the total pool unless the specific activities of intravascular and extravascular proteins are identical. This is only the case if the protein is broken down in all compartments of the body in proportion to the amount of protein in each compartment, and that seems unlikely. If a considerable part of the extravascular compartment is in slow exchange with the plasma pool and if the half-life of the plasma curve is short, the difference in specific activity will be great (28), and the error involved in identifying the turnover rate of the protein with the slope of the plasma curve will be substantial (29). The specific activity will be lowest in the compartment where synthesis of the protein occurs. Gamma globulin is probably synthesized by plasma cells $(30,31)$. After release from the plasma cells the gamma globulin will probably primarily be distributed in the plasma and therefore functionally appear to be synthesized intravascularly. Experimentally, this point of view is supported by the study of Gregoire, McFarlane, and Humphrey (32). No studies on the degradation site of gamma globulin in the dog are available. In man, some have suggested that the degradation occurs intravascularly or in a compartment in rapid equilibrium with plasma because a constant fraction of the plasma radioactivity is excreted each day, even during the process of equilibrium between intravascular and extravascular pools $(26,33)$. Therefore, the turnover of gamma globulin in the present study has been calculated by a method that is based on the assumption that synthesis and catabolism of the protein occur intravascularly (23).

The metabolism of gamma globulin in the dog has been studied by Goldsworthy and Volwiler (34), who used protein biosynthetically labeled with $\mathrm{S}^{35}$ or $\mathrm{C}^{14}$. They found plasma disappearance half-life to be 19 days, seemingly a result quite different from that of the present study. But as pointed out by the authors, the slowest exponential component of the plasma disappearance curve may primarily be due to isotope reutilization.

Intestinal degradation of gamma globulin. It is questionable whether data for loss of protein into isolated short sections of the intestine can be extrapolated to account for loss into the intact, complete intestinal tract. In the present study, however, such a method appears to be justified, since the segments in each dog were isolated from three remote parts: the proximal jejunum, the distal ileum, and approximately at the middle. Furthermore, each segment amounted to 9 to $19 \%$ of the total length, so that the sum of all three segments was 26 to $50 \%$ (mean, $37 \%$ ) (Table III), not a negligible part of the small intestine. Finally, the loss to all three parts was found to be identical. A correlation was found between metabolic clearance and length of intestine $(r=0.73$; $0.02<\mathrm{p}<0.05)$, indicating that the length of the gut may play some role in the degradation of protein. No correlation, however, was found between the length of the intestine and the intestinal clearance $(r=-0.07)$. Another question arises, that is, whether the surgical procedure will cause an artificial exudation of pro- 
tein to the intestinal lumen. It has been shown that subdivision of a segment with a ligature, similar to those at the ends, did not change the transfer of protein (12). Strong evidence is provided by the significant correlation found between exchange rate and the fraction of gamma globulin turnover catabolized in the gut $(r=$ $0.84 ; 0.01<\mathrm{p}<0.02$ ) (Figure 1 ). These two parameters were determined independently in two different experiments, and since no correlation was found between turnover rate and exchange rate, it is unlikely that the experimental procedure had caused any significant alteration of the intestinal mucosa. It is highly improbable that an artifact could be correlated to a physiological parameter. Accordingly, we assume that the present experiments reflect normal conditions and that a substantial fraction of gamma globulin catabolism occurs in the gastrointestinal tract. The intestinal loss of gamma globulin was an average of $40 \%$ of the total catabolism, and whether this value is true may be difficult to evaluate. But if it is accepted that the surgical and experimental procedures have not provoked an artificial exudation of plasma proteins through the wall of the gut, then our figure must be a minimal value for the enteric loss of gamma globulin. On the other hand, the enteric loss may not be much higher because only insignificant proteolysis seems to occur during the 10 minutes' duration of the experiments whether TI is added or not.

The rest of the gastrointestinal tract probably accounts for only a minor fraction of catabolism. Albumin but no gamma globulin has been found by electrophoresis of gastric content $(35,36)$, whereas substantial amounts of gamma globulin have been found in intestinal juice (6). Glenert, Jarnum, and Riemer found that gastric loss was responsible for only about $10 \%$ of albumin catabolism, and therefore it is unlikely that gastric loss of gamma globulin should be that great. The loss of protein to the large intestine is probably negligible (12). If we assume that the gastrointestinal loss of gamma globulin outside the small intestine is at most $10 \%$ of the total catabolism, gastrointestinal loss of gamma globulin accounts for only half of gamma globulin catabolism. Then the question arises: Where does the remaining gamma globulin catabolism take place? For albumin, it has been suggested by Glenert and co-workers that the physiological gastrointestinal catabolism may be rhythmic with a certain "resting value" and with an increment during the process of digesting a meal. The "resting value" corresponds to the value found in these experiments, where no intestinal content will act upon the intestinal wall. Their assumption was based on the fact, which was confirmed in the present study, that instillation of hypertonic $\mathrm{MgSO}_{4}$ solution produced a rise in the passage of labeled protein to the intestinal lumen; this experiment might roughly imitate the physiological conditions following a meal. On the other hand, it might be explained by an osmotic effect on the protein-containing extracellular fluid of the intestinal mucosa, a source of protein that rapidly would be emptied if it were not being filled up owing to a corresponding increment in transfer of protein across the capillary wall. Hitherto it has not been possible to demonstrate degradation of plasma albumin to any significant degree outside the gastrointestinal tract (37). In rats, however, it has been found that the liver is responsible for about $30 \%$ of the catabolism of gamma globulin (38), whereas it is responsible for only a small part of albumin catabolism. Since a fraction of the reticuloendothelial system is localized in the liver and since the major part of gamma globulin is considered to be specific antibodies, it is tempting to assume that gamma globulin is catabolized to some extent during immunological processes.

Virtually nothing is known about the mechanism by which the protein passes from plasma into the intestinal lumen. In the present study, a significant correlation was found between exchange rate and intestinal loss in percentage of total catabolism. The exchange rate of a plasma protein is considered to reflect the ability of the protein to pass the capillary wall, the capillary permeability of the protein. This leads to the conclusion that the capillary permeability of gamma globulin is a determining factor in the intestinal loss of gamma globulin. This point of view is in agreement with the hypothesis that the intestinal loss of plasma proteins in exudative enteropathy is due to an abnormal capillary permeability (39).

Lately, the view that a significant fraction of plasma protein catabolism occurs in the gastrointestinal tract has been opposed $(40,15)$. Waldmann (40) maintains that only a small percentage 
of normal albumin catabolism is due to enteric loss, since only an insignificant fraction of $\mathrm{Cr}^{51}$ labeled albumin given intravenously is recovered in the stool. Since chromium is not absorbed by the gastrointestinal tract, a greater amount is expected in the feces if enteric loss is substantial.

Freeman and Gordon (15) injected I ${ }^{131}$-labeled albumin intravenously together with $\mathrm{I}^{125}$ (as free iodide) after loading the gastrointestinal tract with a resin. They found that the proportion between $I^{131}$ in the stool and in the urine was not greater than the proportion between $\mathrm{I}^{125}$ eliminated by these two routes. Therefore, they claim that the gut is not of quantitative significance as a site of albumin catabolism. This point of view, however, is justified only if $\mathrm{I}^{131}$ after liberation from the protein molecule is not distributed in the iodide pool of the body before excretion in the stool. When $\mathrm{I}^{131}$-labeled albumin was given by mouth to a human subject between resin doses, $66 \%$ of the excreted activity was in the urine and only $34 \%$ bound in the feces. The same distribution was found between urine and feces when $\mathrm{I}^{125}$ (as free iodide) was given intravenously, indicating that it is most likely that $\mathrm{I}^{131}$ is, in fact, distributed primarily in the iodide pool of the body after liberation from the protein molecule, even if it is catabolized intestinally. Therefore, the study of Freeman and Gordon (15) is not evidence against the assumption that a substantial fraction of normal albumin catabolism occurs in the gut.

The problem of the quantity of plasma proteins normally catabolized in the gut is still a controversial subject and remains to be settled ultimately.

\section{SUM MARY}

1) The turnover of $\mathrm{I}^{131}$-labeled gamma globulin was determined in ten dogs. From 13 to $29 \%$ (mean, 21\%) of the plasma pool was catabolized per day, corresponding to from 55 to $188 \mathrm{mg}$ per kg per day.

2) The transfer of gamma globulin from plasma to intestinal lumen in seven of the same dogs was from 21 to $74 \%$ (mean, $38 \%$ ) of the total amount catabolized per day.

3) The transfer was increased about 2.5 times by instillation of hypertonic $\mathrm{MgSO}_{4}$ into the lumen and from 2 to 16 times by clamping of the portal vein.
4) A significant correlation was found between exchange rate with extravascular sites and the fraction of total turnover broken down intestinally, suggesting that the capillary permeability may determine the amount of gamma globulin catabolized in the intestine.

\section{REFERENCES}

1. Citrin, Y., K. Sterling, and J. A. Halsted. The mechanism of hypoproteinemia associated with giant hypertrophy of the gastric mucosa. New Engl. J. Med. 1957, 257, 906.

2. Schwartz, M., and S. Jarnum. Gastrointestinal protein loss in idiopathic (hypercatabolic hypoproteinemia. Lancet 1959, 1, 327.

3. Parkins, R. A. Protein-losing enteropathy in the sprue syndrome. Lancet 1960, 2, 1366.

4. Davidson, J. D., T. A. Waldmann, D. S. Goodman, and R. S. Gordon, Jr. Protein-losing gastroenteropathy in congestive heart-failure. Lancet 1961, 1, 899.

5. Jarnum, S., and M. Schwartz. Hypoalbuminemia in gastric carcinoma. Gastroenterology 1961, 38, 769.

6. Holman, H., W. F. Nickel, Jr., and M. H. Sleisinger. Hypoproteinemia antedating intestinal lesions, and possibly due to excessive serum protein loss into the intestine. Amer. J. Med. 1959, 27, 963.

7. Armstrong, F. B., S. Margen, and H. Tarver. Plasma protein VII. Site of degradation of serum albumin. Proc. Soc. exp. Biol. (N. Y.) 1960, 103, 592.

8. Wetterfors, J., R. Gullberg, S.-O. Liljedahl, L.-O. Plantin, G. Birke, and B. Olhagen. Role of the stomach and small intestine in albumin breakdown. Acta med. scand. 1960, 168, 347.

9. Campbell, R. M., D. P. Cuthbertson, W. Mackie, A. S. McFarlane, A. T. Phillipson, and S. Sudsaneh. Passage of plasma albumin into the intestine of the sheep. J. Physiol. (Lond.) 1961, 158, 113.

10. Jeejeebhoy, K. N., and N. F. Coghill. Measurement of gastrointestinal protein loss by a new method. Gut 1961, 2, 123.

11. Waldmann, T. A. Gastrointestinal protein loss demonstrated by ${ }^{51} \mathrm{Cr}$-labeled albumin. Lancet 1961, 2, 121.

12. Glenert, J., S. Jarnum, and S. Riemer. The albumin transfer from blood to gastrointestinal tract in dogs. Acta chir. scand. 1962, 124, 63.

13. Goldsmith, R. E., C. D. Stevens, and L. Schiff. Concentration of iodine in human stomach and other tissue as determined with radioactive iodine. J. Lab. clin. Med., 1950, 35, 497.

14. Lerner, J., J. Barzelatto, and P. Rojas. Radio-iodine and gastric secretion in Proceedings of the Third World Congress of Gastroenterology. Baltimore, Williams and Wilkins, 1958, vol. 2, p. 95. 
15. Freeman, T., and A. H. Gordon. Human and rat intestine as a site of catabolism of albumin? Presented at the Eleventh Colloquium of Protides of the Biological Fluids, Bruges, Belgium, May 1963.

16. Peterson, E. A., and H. A. Sober. Chromatography of the plasma proteins in The Plasma Proteins, F. W. Putnam, Ed. New York, Academic Press, 1960, vol. 1, p. 105.

17. Tombs, M. P., F. Souter, and N. F. MacLagan. The spectrophotometric determination of protein at 210 m $\mu$. Biochem. J. 1959, 73, 167.

18. McFarlane, A. S. Efficient trace-labelling of proteins with iodine. Nature (Lond.) 1958, 182, 53.

19. Reeve, E. B., and J. J. Franks. Errors in plasma volume measurement from adsorption losses of albumin- $\mathrm{I}^{132}$. Proc. Soc. exp. Biol. (N. Y.) 1956, 93, 299.

20. Yalow, R. S., and S. A. Berson. Chemical and biological alterations induced by irradiation of $\mathrm{I}^{131}$ labeled human serum albumin. J. clin. Invest. 1957, 36, 44.

21. Laurell, C.-B., S. Laurell, and N. Skoog. Buffer composition in paper electrophoresis: considerations on its influence, with special reference to the interaction between small ions and proteins. Clin. Chem. 1956, 2, 99.

22. Laurell, C.-B. Paper electrophoretic pattern after protein staining. Acta med. scand. (suppl.) 1961, 367, 9.

23. Matthews, C. M. E. The theory of tracer experiments with ${ }^{181}$ I-labelled plasma proteins. Phys. in Med. Biol. 1957, 2, 36.

24. Berson, S. A., and R. S. Yalow. Quantitative aspects of iodine metabolism. The exchangeable organic iodine pool, and the rates of thyroidal secretion, peripheral degradation and fecal excretion of endogenously synthesized organically bound iodine. J. clin. Invest. 1954, 33, 1533.

25. Rothschild, M. A., A Bauman, R. S. Yalow, and S. A. Berson. The effect of large doses of desiccated thyroid on the distribution and metabolism of albumin- $\mathrm{I}^{21}$ in euthyroid subjects. $\mathrm{J}$. clin. Invest. 1957, 36, 422.

26. Cohen, S., and T. Freeman. Metabolic heterogeneity of human $\gamma$-globulin. Biochem. J. 1960, 76, 475.
27. Cohen, S., T. Freeman, and A. S. McFarlane. Metabolism of ${ }^{131}$ I labeled human albumin. Clin. Sci. 1961, 20, 161.

28. Berson, S. A., and R. S. Yalow. Distribution and metabolism of $\mathrm{I}^{131}$ labeled proteins in man. Fed. Proc. 1957, 16, 13S.

29. Matthews, C. M. E. Discussion, radioactive isotope in Klinik und Forschung. Berlin, Urban and Schwarzenberg, 1958, vol. 3, p. 310.

30. Bjфrneboe, M., and $H$. Gormsen. Experimental studies on the role of plasma cells as antibody producers. Acta path. microbiol. scand. 1943, 20, 649.

31. Nossal, G. J. V. Antibody production by single cells. III. The histology of antibody production. Brit. J. exp. Path. 1959, 40, 301.

32. Gregoire, F., A. S. McFarlane, and J. H. Humphrey. Isotopic studies of globulin production in extravascular sites. Progr. Nuclear Energy (Biol.) 1958, 2, 247.


Scand. J. clin. Lab. Invest. (suppl.) 1963, in press.

34. Goldsworthy, P. D., and W. Volwiler. Mechanism of protein turnover studied with cystein- $\mathrm{C}^{35}$, lysin- $C^{\mathbf{1 4}}$ doubly labeled plasma proteins of the dog. J. biol. Chem. 1958, 230, 817.

35. Gullberg, R., and B. Olhagen. Electrophoresis of human gastric juice. Nature (Lond.) 1959, 184, 1848.

36. Heiskell, C. L., T. Wada, S. J. Stempien, M. Fukuda, S. Nakagawa, A. Yachi, A. Dagradi, and C. M. Carpenter. Normal serum proteins in gastric juice. Gastroenterology 1961, 40, 775.

37. Tarver, H., F. B. Armstrong, J. R. Debro, and S. Margen. Catabolism of plasma protein in the gut. Ann. N. Y. Acad. Sci. 1961, 94, 23.

38. Cohen, S., A. H. Gordon, and C. Matthews. Catabolism of $\gamma$-globulin by the isolated perfused rat liver. Biochem. J. 1962, 82, 197.

39. Jarnum, S. Protein-losing Gastroenteropathy. Oxford, Blackwell, 1963, p. 200.

40. Waldmann, T. A. The use of chromium labeled albumin in the study of protein losing enteropathy. Presented at the Eleventh Colloquium of Protides of the Biological Fluids, Bruges, Belgium, May 1963. 